\title{
The Effect of Gratefulness and Forgiveness on Quality of Life
}

\author{
Novita Surya Ningsih \\ Social Development, Faculty of Social and Political Sciences, Mulawarman University, Indonesia
}

http://dx.doi.org/10.18415/ijmmu.v8i9.2920

\begin{abstract}
The research subjects were 105 students from the Faculty of Economics, Law, Politics and Psychology, Muhammadiyah University of East Kalimantan. This study uses a quantitative approach with data analysis using the help of the Statistics Package for Social Science (SPSS) 21.0 for windows program. The results showed that there was a significant influence between gratitude and forgiveness on quality with an $F$ value of 15.302 and $p$ of 0.000 which had an effect contribution value (R2) of 23.3 percent. There is a significant positive effect between thanksgiving on quality of life with a beta value of 0.402 , $t$ count of 3.556 and $p$ of 0.001 . There is a significant positive effect between forgiveness on quality of life with a beta value of $0.181, \mathrm{t}$ count of 2.034 and $\mathrm{p}$ of 0.045
\end{abstract}

Keywords: Gratitude; Forgiveness; Quality of life

\section{Introduction}

The priority issue in many developing countries is currently discussing the quality of life which is used to describe the welfare of students in the environment (Liao, Fu, \& Yi 2015). Based on the research that has been done, it is stated that the quality of life of the Indonesian people is still relatively low. Indonesia is ranked 108th out of 177 countries, this ranking is still below Singapore, which is 25th, Brunei Darussalam 34th, Malaysia 61st, Thailand 74th and the Philippines 84th .(Widiyanto 2012)

Prastiwi (2012) defines quality of life as an individual's perception of his condition by looking at the physical, psychological, social and environmental aspects that aim to achieve satisfaction and goodness in all aspects of life so that satisfaction will lead to a quality life. Sarafino and Smith (2014) suggest that quality of life is an individual assessment of the improvement during life experienced by individuals and is related to the ability to carry out activities, energy and discomfort, positive and negative feelings, personal control, interpersonal relationships, comfort in activities, material for personal and intellectual growth.

There are four aspects of quality of life, namely, physical aspects which include daily activities, energy, fatigue, pain, discomfort, sleep, and rest experienced by individuals, the ability to carry out activities and physical health. Psychological aspects are mental descriptions related to body shape and appearance, negative feelings, positive feelings, self-esteem, thought processes, learning, and concentration, as well as everything that includes a person's mental health. Then the Social Aspect, which includes how interpersonal relationships that function in groups and positive intrapersonal relationships, individual sexual activities, broad friendships, and one's role in society. The last is the environmental aspect where good environmental conditions also support a good quality of life. (Prastiwi, 2012) 
The view of the quality of life depends on how a person thinks and how to solve problems used by students. Differences in views of life will affect the perceived quality of life. The more people get older, the more problems that arise, especially for students who are entering the age of 20 , so it is necessary to instill a sense of gratitude to improve their quality of life.

Gratitude is a variable that is often associated with other positive variables. Gratitude has a positive relationship with subjective happiness. People who are grateful can increase positive feelings in themselves (Watkins, 2013). Meanwhile, according to Boleyn-Fitzgerald (2016) states that gratitude is raised as a sense of gratitude, gratitude and happiness as a response to receiving gifts, both gifts that are felt by a person in real terms, in a comfortable, safe, and occur naturally or when under pressure, problems. or unpleasant situations from other people or the environment.

Gratitude has three aspects, namely, the sense of abundance is a condition when the individual who always feels his life is surrounded by abundance and the individual does not feel lacking in anything so that the individual always feels grateful for everything he has. The simple aspect of appreciation is a condition where the individual considers that his whole life is a gift from the power, then the person will be grateful for the gift and will bring up more appreciation in a simple form for the goodness that has been obtained. The aspect of appreciation of others is a form of individual appreciation for other individuals as a form of response to the presence of others. In addition, grateful individuals must realize that giving appreciation is important (Watkins, 2013)

Gratitude can have a quite relevant influence on the quality of life, this is evidenced by students who are easily grateful that they can make life calmer because they live life according to their abilities. This is evidenced by the theory put forward by Toussaint et al (2017), which states that gratitude has a positive relationship to quality of life, where gratitude can be proposed to be one of the values in positive psychology for individual quality of life.

According to Nashori (2014) forgiveness can be interpreted as a willingness to leave unpleasant things that come from interpersonal relationships by growing and developing more positive relationships, thoughts, and feelings with people who have done less pleasant actions. Meanwhile, Martin (2013) defines forgiveness as choosing to be happy by letting go of the desire in terms of taking revenge on others who have made mistakes where individuals must be able to rebuild the positive side by releasing themselves from negative things leading to freedom that helps a person to lead to a loving, healthy and happy relationship.

Aspects of forgiveness are divided into three aspects, namely the emotional aspect that relationship with the feelings of the individual victim to the perpetrator. The indicator of forgiveness from the emotional dimension is leaving feelings of anger, hatred, and hurt, being able to control emotions when treated unpleasantly. Aspects of cognition that have to do with individual thinking about the unpleasant things that are experienced. Some indicators of forgiveness from the cognitive dimension are leaving a negative assessment of the perpetrator, having a reasoned explanation for the painful treatment, having a balanced view of the perpetrator. The interpersonal aspect is related to interpersonal encouragement to forgive others .(Nashori, 2014)

Students who can forgive other people's mistakes will certainly have better physical and psychological health than students who are difficult to forgive, this is supported by Toussaint and Webb (2015) forgiveness can improve mental health, and spiritual health. Forgiveness can make teenagers healthier and happier in their daily lives so that they can improve their quality of life. This study aims to see whether there is an effect of forgiveness and gratitude on the quality of life of students of the Faculty of Economics, Law, Politics and Psychology, Muhammadiyah University of East Kalimantan. 


\section{Research Methods}

This study uses a quantitative method based on the philosophy of positivism which is used to examine a particular population or sample. The data collection used is a research instrument with quantitative or statistical data analysis which aims to test the established hypothesis (Sugiyono, 2011).

\section{Research Subject}

The subjects of this study were 105 students of the Faculty of Economics, Law, Politics and Psychology, Muhammadiyah University of East Kalimantan. The number of samples used in this study were 105 students who were selected through simple random sampling technique. The research subjects were dominated by members aged 18-19 years, amounting to 69.5 percent and dominated by female members, amounting to 76 members.

\section{Method of Collecting Data}

The data collection method used is a measurement tool or instrument. The research instrument used consisted of three, namely the quality-of-life scale consisting of 32 statement items, the gratitude scale consisting of 24 statement items and the forgiveness scale consisting of 24 statement items. This study uses a Likert type scale. The scale used is arranged using a Likert form with four alternative answers. Then divided into favorable and unfavorable statements with four alternative answers. Then after being tested for validity there are 2 items that fall on the quality-of-life scale, so that the valid items become 30 statements.

\section{Data Analysis Technique}

Data analysis was carried out for processing research data using multiple regression analysis to determine how much influence and predictive ability the two independent variables (gratitude and forgiveness) had on the dependent variable (quality of life). The analysis was carried out using the SPSS (Statistical Packages for Social Science) computer program version 21.0 for Windows. Prior to the hypothesis analysis test, an assumption test will be conducted which consists of Normality Test, Linearity Test, Multicollinearity Test, Heteroscedasticity Test and Autocorrelation Test.

\section{Research Result}

The following are the results of multiple linear regression research listed in the full and stepwise regression models:

Full Model Regression Analysis Hypothesis Test Results

Table 6. Analysis Test Results Full Model Regression

\begin{tabular}{lcccc}
\hline Variable & F count & F table & $\mathbf{R}^{\mathbf{2}}$ & $\mathbf{P}$ \\
\hline Quality of Life (Y1) & 15.505 & 3.09 & 0.233 & 0.000 \\
$\begin{array}{l}\text { Gratitude (X1) } \\
\text { Forgiveness (X2) }\end{array}$ & & & \\
\hline
\end{tabular}


The results of the hypothesis test of the full regression analysis show that $\mathrm{F}$ count $>\mathrm{F}$ table, which means that gratitude and forgiveness on the quality of life have a very significant effect with the value of $F$ $=15.505, \mathrm{R} 2=0.233$, and $\mathrm{p}=0.000$. This means that the major hypothesis in this study is accepted.

\section{Results of Hypothesis Testing for Staged Model Regression Analysis}

Table 7. Regression Analysis Test Results Gradual Mode

\begin{tabular}{|c|c|c|c|c|}
\hline Variable & Beta & $T$ count & T table & $\mathbf{P}$ \\
\hline $\begin{array}{l}\text { Gratitude (X1) } \\
\text { Quality of Life (Y) }\end{array}$ & 0.402 & 3.556 & 1983 & 0.001 \\
\hline $\begin{array}{l}\text { Forgiveness (X2) } \\
\text { Quality of Life (Y) }\end{array}$ & 0.181 & 2.034 & 1983 & 0.045 \\
\hline
\end{tabular}

The results of the hypothesis test of the stepwise regression analysis show that $t$ count $>t$ table, which means that there is a significant influence between gratitude on quality of life with beta $=0.402, \mathrm{t}$ count $=3.556$, and $p=0.001(\mathrm{p}<0.05)$. Then the forgiveness of quality of life shows $t$ count $<t$ table which means there is a significant effect with beta $=0.181$, $\mathrm{t}$ count $=2.034$ and $\mathrm{p}=0.045(\mathrm{p}>0.05)$.

\section{Discussion}

Based on the results of the full model regression analysis hypothesis test, the results showed that $\mathrm{F}$ count $>\mathrm{F}$ table with $\mathrm{F}=15.302$ and $\mathrm{p}=0.000(\mathrm{p}<0.05)$. This means that the major hypothesis in this study is accepted, which means that gratitude and forgiveness for the quality of life have a significant effect.

The contribution of the influence (R2) of gratitude and forgiveness to the quality of life is 0.233 , this indicates that 23.3 percent of the variation in the quality of life can be explained by gratitude and forgiveness. While the remaining 76.7 percent is explained by other variables or other causes not examined in this study.

In line with the aspects of quality of life according to Prastiwi (2012) it is divided into four aspects, namely physical, psychological, social and environmental aspects. Physical aspects are functional status in daily life, energy, fatigue, pain, discomfort, sleep and rest experienced by individuals, ability to carry out activities and physical health. Psychological aspects are mental descriptions related to body shape and appearance, negative feelings, positive feelings, self-esteem, thought processes, learning, and concentration, and everything that includes one's mental health, positive feelings are closely related to gratitude and forgiveness behavior. This is supported by research according to (Toussaint \& Friedman,

Based on the results of the hypothesis test of the stepwise regression analysis, gratitude for the quality of life of the students of the Faculty of Economics, Law, Politics and Psychology, Muhammadiyah University of East Kalimantan shows that there is a significant effect. This is evidenced by the value of beta $=0.402$, $\mathrm{t}$ count $=3.556$, and $\mathrm{p}=0.001(\mathrm{p}<0.05)$ which means the higher the gratitude, the higher the quality of life of students and vice versa, the lower the gratitude, the lower the quality of life of students.

The above is in line with the results of previous research conducted by (Wijayanti \& Listiyandini 2020), which states that gratitude has a significant influence on the quality of life of the psychological welfare dimension with a contribution of $10.7 \%$ to the dimensions of social support and peer support with a contribution of $2.4 \%$ and the rest influenced by other aspects. This is in line with research conducted by Hidayat \& Gamayanti (2020) which states that the variable of gratitude has a significant correlation with quality of life with an alpha of $0.004<0.005$, which means that the higher the gratitude, the higher the quality of life. 
In accordance with research conducted that gratitude for the quality of life has a positive direction. This is supported by research conducted by Toussaint et al (2017) which states that gratitude has a positive relationship to quality of life, where gratitude can be suggested to be one of the values in positive psychology to improve quality of life.

Based on the results of the stepwise regression hypothesis test, forgiveness on the quality of life of the students of the Faculty of Economics, Law, Politics and Psychology, Muhammadiyah University, East Kalimantan, shows that there is a significant effect. This is evidenced by the value of beta $=0.181$, $\mathrm{t}$ count $=2.034$, and $\mathrm{p}=0.045(\mathrm{p}<0.05)$ which means the higher the forgiveness, the higher the quality of life of students and vice versa, the lower the forgiveness, the lower the quality of life of students.

This is in line with research conducted by Rana, Nandinee, and Vincent (2014) which states that forgiveness has a significant contribution to adolescent happiness. The higher the forgiveness, the higher the happiness felt. In this case, happiness enters into the psychological aspect of quality of life.

Adolescents who are able to forgive will have a happier life, this is because they are able to manage the negative emotions they are feeling. This is in line with research conducted by Feldman and Steptoe (2013) which explains that an individual's ability to control emotions will affect psychological conditions such as happiness, where emotional control is a fairly effective factor to increase happiness and reduce stress levels. This means that the higher the forgiveness, the higher the happiness that supports a good quality of life for students.

\section{Conclusion}

Based on the research that has been done, it can be concluded that the major hypothesis in this study is accepted, namely there is a significant influence between gratitude and forgiveness on the quality of life in students of the Faculty of Economics, Law, Politics and Psychology, Muhamadiyah University, East Kalimantan.

Then the minor hypothesis in this study is also accepted. First, there is a positive and significant effect between gratitude and quality of life for students of the Faculty of Economics, Law, Politics and Psychology, Muhammadiyah University, East Kalimantan. Second, there is a positive and significant effect between forgiveness on the quality of life in students of the Faculty of Economics, Law, Politics and Psychology, Muhamadiyah University, East Kalimantan.

\section{Suggestion}

\section{For Students}

Students as the next generation of the nation should be able to control themselves to keep doing things that tend to be positive to improve the quality of life. Quality of life is a condition that tends to be positive because it contains aspects of gratitude and forgiveness which are positive actions as well. Positive things that can be done such as being grateful for the blessings that have been given and forgiving mistakes made by others, maintaining good relationships with others, taking care of negative thoughts and feelings that interfere with life so as to improve the quality of life of students. So with gratitude and forgiveness will make the quality of life for the better.

\section{For the Next Researcher}

Further researchers who are interested in researching the quality of life should examine more broadly the factors that can affect the quality of life considering that in the results of this study the variables used have a fairly small effect on the quality of life, so that future researchers are expected to find better findings from research that has been done. 


\section{Reference}

Boleyn-Fitzgerald, P. (2016). Perspectives on gratitude: An interdisciplinary approach. New York : Routledge.

Feldman, PJ, \& Steptoe, A. (2013). Psychosocial and Sociosocial factors associated with glycated hemoglobin in nondiabetic middle-aged men and women. Health Psychology, 22(4), 398-405.

Hidayat, IN, \& Gamayanti, W. (2020). Envy, Gratitude and Quality of Life for People Who Experience Psychosomatics. Psympathic: Scientific Journal of Psychology, 7(1), 79-92.

Liao, P., Fu, Y., \& Yi, C. (2015). Perceived Quality of Life in Taiwan and Hong Kong: AN Intra-Culture Comparison. Journal of Happiness Studies, 6, 43-67.

Martin. (2013). Forgivenessis power: a user'sguidetowhyandhowtoforgive. Scotland: FindhornPress.

McCullough, ME, Kimeldorf, MB, \& Cohen, AD (2008). An adaptation for altruism: The social causes, social effects, and social evolution of gratitude. Current directions in psychological science, 17(4), 281285.

Nashori, F. (2014). Psychology of forgiveness. Yogyakarta: Safiria Insania Press.

Prastiwi, TF (2012). Quality of life of cancer patients. Journal of UNES, 1(1), 21-27

Rana, S., Hariharan, M., Nandinee, D., \& Vincent, K. (2014). Forgiveness: A determinant of adolescents' happiness. Indian Journal of Health and Wellbeing, 5(9), 1119-1123.

Sarafino, EP, \& Smith, TW (2014). Health psychology: biopsychosocial interactions. London: John Wiley $\&$ Sons.

Sugiyono. (2011). Statistics for research. Bandung: Alphabeta.

Toussaint, L., \& Friedman, P. (2009). Forgiveness, gratitude, and well-being: The mediating role of affect and beliefs. Journal of Happiness Studies, 10(6), 635-654

Toussaint, L., \& Webb, JR (2015). Gender differences in the relationship between empathy and forgiveness. Journal of Social Psychology, 145(6), 673-685

Toussaint, L., Sirois, F., Hirsch, J., Weber, A., Vajda, C., Schelling, J., Kohls, N., \& Offenbacher, M. (2017). Gratitude mediates quality of life differences between fibromyalgia patients and healthy controls. Qual Life Res, 26(9), 2449-2457

Watkins, P., Woodward, K., Stone, T., \& Kolts, R. (2013). Gratitude and happiness: development of a measure of gratitude, and relationship with subjective well-being. Social Behavior and Personality, 31(5), 431-452.

Wijayanti, S., Rahmatika, R., \& Listiyandini, RA (2020). The Contribution of Gratitude in Improving the Quality of Health Life for Adolescents in Orphanages. Psycho Idea, 18(1), 33-44 
Widiyanto, SP, \& Si, M. (2012). Strategy for Improving the Quality of Human Life in Indonesia. Online at http://library. uns. air conditioning. en/ journal, 25(7), 1-13.

\section{Copyrights}

Copyright for this article is retained by the author(s), with first publication rights granted to the journal.

This is an open-access article distributed under the terms and conditions of the Creative Commons Attribution license (http://creativecommons.org/licenses/by/4.0/). 